\title{
UNCITRAL Cases
}

AWG Group v. Argentine Republic

Decision on the Proposal for the Disqualification of a Member of the Arbitral Tribunal (Oct. 22, 2007) (Suez I).

Decision on a Second Proposal for the Disqualification of a Member of the Arbitral Tribunal (May 12, 2008) (Suez II).

BG Group plc v. The Republic of Argentina (BG Group)

United States District Court for the District of Columbia, Case No. $\mathbf{0 8 - 0 4 8 5}$ (RBW), Petition to Vacate or Modify Arbitration Award (Mar. 21, 2008), available at http://ita.law.uvic.ca/documents/BGvArgentina.pdf.

Canfor Corporation v United States (Canfor)

Select documents available at http://www.state.gov/s/l/c7424.htm (last accessed on Dec. 30, 2016).

cc/Devas v. Republic of India (cc/Devas)

PCA Case No. 2013-09, Decision on the Respondent's Challenge to the Hon. Marc Lalonde as Presiding Arbitrator and Prof. Francisco Orrego Vicuña as CoArbitrator (Sept. 30, 2013), avalable at http://www.italaw.com/sites/default/files/ case-documents/italaw3161.pdf.pdf.

EnCana Corporation v. Republic of Ecuador (EnCana)

LCIA Secretariat, LCIA Case No. UN3481, Partial Award on Jurisdiction (Feb. 27, 2004), available at http://www.italaw.com/sites/default/files/case-documents/ ita0283_o.pdf.

Eureko B.v. v. Republic of Poland (Eureko)

Court of First Instance of Brussels, R.G. 2006/1542/A, Judgement [sic] on the Request for Recusal of Judge Schwebel (Dec. 22, 2006), English translation available at http://www.italaw.com/documents/Eureko-arbitratorchallenge.pdf.

GAMI Investments, Inc. v. The Government of the United Mexican States

Select documents available at http://www.state.gov/s/l/c7119.htm (last accessed on Dec. 30, 2016).

Grand River Enterprises Six Nations Ltd et al v. United States of America (Grand River) ICSID Secretary-General, Decision on the Challenge to Arbitrator James Anaya (Nov. 28, 2007), available at http://www.italaw.com/sites/default/files/case -documents/itao382_o.pdf.

ICS Inspection and Control Services Limited (United Kingdom) v. The Republic of Argentina (ICS)

PCA Case No. 2010-9, Decision on Challenge to Arbitrator (Dec. 17, 2009), available at http://italaw.com/sites/default/files/case-documents/ita0415.pdf. 
National Grid plc v. The Republic of Argentina (National Grid)

Division of the LCIA Court, LCIA Case No. UN 7949, Decision on the Challenge to Mr. Judd L. Kessler (Dec. 3, 2007), available at http://www.iisd.org/pdf/2008/ itn_lcia_rulling_kessler_challenge.pdf (National Grid II)

Telekom Malaysia Berhad v. Republic of Ghana (Telekom Malaysia)

District Court of The Hague, Petition No. HA/RK 2004.667, Decision on the Challenge of Prof. E. Gaillard (Oct. 18, 2004) (Telekom Malaysia I), English translation available at http://www.italaw.com/cases/1091.

District Court of The Hague, Petition No. HA/RK 2004.788, Decision on the Challenge of Prof. E. Gaillard (Nov. 5, 2004) (Telekom Malaysia II), English translation available at http://www.italaw.com/cases/1200.

Vito G. Gallo v. Government of Canada (Vito Gallo) ICSID Deputy Secretary-General, Decision on the Challenge to Mr.J. Christopher Thomas, Q.C. (Oct. 14, 2009), available at http://italaw.com/documents/Gallo -Canada-Thomas_Challenge-Decision.pdf. 